Article

\title{
Iron Oxide Particles Alter Bacterial Uptake and the LPS-Induced Inflammatory Response in Macrophages
}

\author{
Lewis J. Williams ${ }^{1}$, Stephen G. Tristram ${ }^{2}$ (D) and Graeme R. Zosky ${ }^{1,3, *(\mathbb{D}}$ \\ 1 Tasmanian School of Medicine, University of Tasmania, 7000 Hobart, Australia; Lewis.Williams@utas.edu.au \\ 2 School of Health Sciences, University of Tasmania, 7250 Launceston, Australia; Stephen.Tristram@utas.edu.au \\ 3 Menzies Institute for Medical Research, University of Tasmania, 7000 Hobart, Australia \\ * Correspondence: Graeme.Zosky@utas.edu.au; Tel.: +61-3-6226-6921
}

Citation: Williams, L.J.; Tristram, S.G.; Zosky, G.R. Iron Oxide Particles Alter Bacterial Uptake and the

LPS-Induced Inflammatory Response in Macrophages. Int. J. Environ. Res. Public Health 2021, 18, 146. https://doi.org/10.3390/ ijerph18010146

Received: 24 November 2020 Accepted: 24 December 2020 Published: 28 December 2020

Publisher's Note: MDPI stays neutral with regard to jurisdictional clai$\mathrm{ms}$ in published maps and institutional affiliations.

Copyright: (C) 2020 by the authors. Licensee MDPI, Basel, Switzerland. This article is an open access article distributed under the terms and conditions of the Creative Commons Attribution (CC BY) license (https:// creativecommons.org/licenses/by/ $4.0 /)$.
Abstract: Exposure to geogenic (earth-derived) particulate matter (PM) is linked to severe bacterial infections in Australian Aboriginal communities. Experimental studies have shown that the concentration of iron in geogenic PM is associated with the magnitude of respiratory health effects, however, the mechanism is unclear. We investigated the effect of silica and iron oxide on the inflammatory response and bacterial phagocytosis in macrophages. THP-1 and peripheral blood mononuclear cell-derived macrophages were exposed to iron oxide (haematite or magnetite) or silica PM with or without exposure to lipopolysaccharide. Cytotoxicity and inflammation were assessed by LDH assay and ELISA respectively. The uptake of non-typeable Haemophilus influenzae by macrophages was quantified by flow cytometry. Iron oxide increased IL-8 production while silica also induced significant production of IL-1 $\beta$. Both iron oxide and silica enhanced LPS-induced production of TNF- $\alpha$, IL-1 $\beta$, IL-6 and IL-8 in THP-1 cells with most of these responses replicated in PBMCs. While silica had no effect on NTHi phagocytosis, iron oxide significantly impaired this response. These data suggest that geogenic particles, particularly iron oxide PM, cause inflammatory cytokine production in macrophages and impair bacterial phagocytosis. These responses do not appear to be linked. This provides a possible mechanism for the link between exposure to these particles and severe bacterial infection.

Keywords: geogenic; particulate matter; macrophages; inflammatory cytokines; NTHi

\section{Introduction}

Bronchiectasis is a chronic obstructive lung disease that develops as a result of prolonged inflammation leading to structural changes in the airways and recurrent infections [1]. The prevalence of bronchiectasis is almost three times higher in Australian Aboriginals living in rural communities [2] and these communities have among the highest prevalence of bronchiectasis in children globally [3]. While these communities often have comparatively higher rates of smoking and restricted access to medical services [4-6], other environmental factors may be contributing to this disease disparity [7-9]. Previous studies have suggested that exposure to air pollution is associated with increased bronchiectasis exacerbations and mortality [10,11]. While Aboriginal communities are typically exposed to lower levels of traffic-derived pollution than urban centres, they are exposed to high concentrations of geogenic (earth-derived) particulates which consist primarily of iron oxide and silica [5,7]. The potential contribution of these airborne particles to the burden of bronchiectasis is unclear.

Non-typeable Haemophilus influenzae (NTHi) is the most common pathogen isolated from individuals with bronchiectasis [2,12-15]. We have previously shown that exposure to geogenic particles increases viral susceptibility in vivo [16] and has the capacity to alter NTHi growth in vitro [17]. However, the impact of these particles on the cellular response to NTHi is largely unknown. 
Given the critical role of macrophages in the response to inhaled particulates $[18,19]$ and pathogenic bacteria [20], we assessed the production of inflammatory cytokines in macrophages in response to iron oxide particles alone, or in combination with silica, with or without prior exposure to bacterial endotoxin. We also investigated the effect of the particles on the phagocytic capacity of macrophages to NTHi and potential mechanisms explaining the differences we observed.

\section{Materials and Methods}

\subsection{Particle Preparation}

Haematite $\left(\mathrm{Fe}_{2} \mathrm{O}_{3}\right.$ 310050; Sigma-Aldrich, St. Louis, MO, USA), magnetite $\left(\mathrm{Fe}_{3} \mathrm{O}_{4}\right.$ 310069; Sigma-Aldrich, St. Louis, $\mathrm{MO}, \mathrm{USA})$ and $\alpha$-quartz $\left(\mathrm{SiO}_{2} 1878 \mathrm{~B}\right.$; National Institute of Standards and Technology, Gaithersburg, MD, USA) particles $(<5 \mu \mathrm{m})$ were used for cell exposure experiments. Haematite and magnetite were chosen as common forms of naturally occurring iron oxide with different redox potentials (Fe II and Fe III respectively) which may impact on the cellular response (26). Particles were exposed to UV light for two hours prior to experimentation and washed with centrifugations and saline to remove any bacterial contamination. Particle samples were dispersed in RPMI-1640 media and vortexed thoroughly for $30 \mathrm{~s}$ to ensure even distribution of particles within the suspension before application to the cells.

\subsection{Cell Culture}

The human leukaemic monocyte cell line, THP-1 (Sigma-Aldrich, St. Louis, MO, USA), was cultured in $25 \mathrm{~cm}^{2}$ flasks (CLS430639; Corning Inc., Corning, NY, USA), using RPMI1640 (30-2001; American Type Culture Collection, Manassas, VA, USA) supplemented with 10\% foetal bovine serum (FBS; Gibco A31605, Life Technologies, Carlsbad, CA, USA) and $1 \%$ penicillin-streptomycin (P4333; Sigma-Aldrich, St. Louis, MO, USA) at $37{ }^{\circ} \mathrm{C}$ in a humidified atmosphere of $5 \% \mathrm{CO}_{2}$.

\subsection{Peripheral Blood Mononuclear Cell (PBMC) Isolation and Culture}

The following collection of human blood has been approved by the Tasmanian Health and Medical Human Research Ethics Committee (H0016505). Peripheral blood mononuclear cells (PMBCs) were isolated from six healthy adults aged between 20 and 50 years of age. Briefly, $32 \mathrm{~mL}$ of blood was collected from each patient using EDTA-BD Vacutainers (366643; Becton Dickinson, Franklin Lakes, NJ, USA). Samples were incubated at room temperature for $20 \mathrm{~min}$ with gentle mixing. Blood was aseptically layered onto $4 \mathrm{~mL}$ of Histopaque (10771; Sigma-Aldrich, St. Louis, MO, USA) in a 1:1 ratio before being centrifuged at $100 \mathrm{~g}$ for $30 \mathrm{~min}$. Density gradient separation allowed the isolation of mononuclear cells which were then washed twice by centrifugation at $300 \mathrm{~g}$. Cells were resuspended in serum-free RPMI-1640 and seeded at a density of $6 \times 10^{6}$ cells $/ \mathrm{mL}$. Cells were incubated for $1 \mathrm{~h}$ at $37{ }^{\circ} \mathrm{C}$ in a humidified atmosphere of $5 \% \mathrm{CO}_{2}$ and then washed twice to remove non-adherent cells, providing pure monocyte cultures. RPMI-1640 media containing 10\% FBS was supplemented with $2 \mathrm{ng} / \mathrm{mL}$ of granulocyte-macrophage colonystimulating factor (GM-CSF 300-03; Pepro Tech Inc., Rocky Hill, NJ, USA) for 12 days, refreshing every 3 days.

\subsection{Cell Exposure Trials}

Cells were suspended in RPMI-1640 with 10\% FBS and seeded into 12-well plates (CLS3512; Corning Inc., Corning, NY, USA) at a concentration of $6 \times 10^{5}$ cells/well. THP-1 cells were differentiated into macrophages by exposure to $25 \mu \mathrm{M}$ of Phorbol 12-myristate 13-acetate (PMA P1585; Sigma-Aldrich, St. Louis, MO, USA) for 48 h, followed by recovery in PMA-free growth media for $24 \mathrm{~h}$. Cells were then either exposed to $10 \mathrm{ng} / \mathrm{mL} E$. Coli-derived lipopolysaccharide (LPS L4391; Sigma-Aldrich, St. Louis, MO, USA) or LPSfree media for $4 \mathrm{~h}$ before particle exposure. To investigate the dose-dependent effects of haematite, magnetite and silica individually, cells were exposed to $0,10,25$ or $50 \mu \mathrm{g} / \mathrm{mL}$ of 
each particle type. Concentrations were chosen to be consistent with similar PM toxicology studies (30-35). Cytotoxicity and the production of interleukin (IL)-1 $\beta$, IL-6, IL-8 and tumour necrosis factor- $\alpha$ (TNF- $\alpha$ ) were assessed after $24 \mathrm{~h}$ of particulate exposure. The individual particle effects were established before assessing the impact of silica and iron, in combination, on the response. Cells were exposed to a 2:1 silica: iron ratio, which reflects the proportion of these elements in real-world particles (12). The total dose used $(50 \mu \mathrm{g} / \mathrm{mL})$ was chosen based on the initial experiments, to reflect a concentration that would not cause large levels of cytotoxicity but was sufficient to produce a cytokine response. Cytotoxicity and cytokine production were assessed after $24 \mathrm{~h}$ of exposure to particulates as described previously.

Subsequent bacterial internalisation experiments used the same $50 \mu \mathrm{g} / \mathrm{mL}$ particle concentration for $24 \mathrm{~h}$. All experiments were repeated in six independent trials. Each trial was conducted on a different day using fresh cell cultures and reagents including particles and LPS preparations to allow valid statistical comparisons between exposure groups.

\subsection{Cytotoxicity}

The LDH assay (G1780; Promega Corporation, Madison, WI, USA) was used as a marker of cytotoxicity. LDH levels were measured according to the manufacturer's instructions. Absorbance was read with the Spectra Max M2 plate-reader (Molecular Devices, San Jose, CA, USA).

\subsection{Inflammatory Cytokine Production}

Levels of human interleukin-1 $\beta$ (IL-1 $\beta$; R\&D Systems DY201), interleukin-6 (IL-6; R\&D Systems DY206), interleukin-8 (IL-8; R\&D Systems DY208) and tumour necrosis factor- $\alpha$ (TNF- $\alpha$; R\&D Systems DY210) in the cell supernatant $24 \mathrm{~h}$ post-exposure to the particles were assessed by enzyme-linked immunosorbent assay (ELISA) according to the manufacturer's instructions. The minimum detection limits for IL- $1 \beta$, IL- 6 , IL- 8 and TNF- $\alpha$ were $7.81,9.38,31.3$ and $15.6 \mathrm{pg} / \mathrm{mL}$ respectively. Absorbance was read with the Spectra Max M2 plate-reader (Molecular Devices, San Jose, CA, USA).

\subsection{Bacterial Isolates and Culture}

Eight clinical pathogenic strains of NTHi were obtained from the University of Tasmania Culture Collection and identity was confirmed by genetic markers. Bacteria were cultured on blood agar and transferred to a brain heart infusion broth overnight before exposure to cells. Bacteria were cultured on an orbital shaker at $200 \mathrm{rpm}$ at $37^{\circ} \mathrm{C}$ in atmospheric $\mathrm{CO}_{2}$.

\subsection{Bacterial Exposure}

Bacterial broth suspensions were standardised to an optical density of 0.6 at $600 \mathrm{~nm}$ $\left(\mathrm{OD}_{600}\right)$. From this, $1 \mathrm{~mL}$ of each bacterial suspension was centrifuged at $6000 \mathrm{~g}$ for $10 \mathrm{~min}$ before three washes in sterile-filtered phosphate-buffered saline (PBS). Bacteria were resuspended in a total of $1 \mathrm{~mL}$ of PBS each and fluorescently tagged with $1 \mu \mathrm{L}$ CellTrace Far Red (C34564; Thermo Fisher Scientific, Waltham, MA, USA) for $20 \mathrm{~min}$ at room temperature in the absence of light. Bacteria were diluted to a 1:30 concentration before $30 \mu \mathrm{L}$ of bacterial suspension was applied per well in a 96-well plate and incubated for $3 \mathrm{~h}$ at $37^{\circ} \mathrm{C}$ and $5 \%$ $\mathrm{CO}_{2}$.

After bacterial exposures, samples were washed using PBS and exposed to their respective growth media supplemented with $200 \mu \mathrm{g} / \mathrm{mL}$ of gentamicin to remove remaining extracellular bacteria. Samples were incubated for $4 \mathrm{~h}$ at $37^{\circ} \mathrm{C}$ and $5 \% \mathrm{CO}_{2}$. Following PBS washing, trypsin detached cell samples were made to a final volume of $200 \mu \mathrm{L} /$ well for flow cytometry. 


\subsection{Flow Cytometry}

Fluorescent staining was analysed using a BD Facscanto II flow cytometer (BD Biosciences, San Jose, CA, USA). Data were analysed using FCS Express 6 (DeNovo software, Pasadena, CA, USA), using fluorescence minus one (FMO) controls to determine gating strategies. Compensation was performed using single colour stained cells, and compensation matrices were calculated and applied. Cell populations were distinguished based on forward scatter (FSC) height and width (see Supplementary Materials Figure S1). Gating strategies mitigated the presence of any remaining extracellular bacteria, while intracellular bacteria were quantified using the median fluorescent intensity.

\subsection{Statistical Analysis}

Comparisons between groups were made using repeated measures one-, and two-way ANOVA. When significance was determined for the main factors by ANOVA, the HolmSidak post-hoc test was used to examine individual between group differences. Where necessary, the data were log transformed to satisfy the assumptions of normal distribution of the error terms and homoscedasticity of the variance. All data are presented as mean (SD) and values of $p<0.05$ were considered statistically significant. All statistical analyses were conducted using SigmaPlot (v12.5 Systat, San Jose, CA, USA).

\section{Results}

\subsection{Effect of Silica and Iron Oxide PM on Inflammation}

\subsubsection{Cytotoxicity}

Quartz caused a dose-dependent increase in LDH production, with an increase observed at the $25 \mu \mathrm{g} / \mathrm{mL}$ concentration $(p<0.001)$ and a further increase at $50 \mu \mathrm{g} / \mathrm{mL}$ $(p<0.001)$ (Figure 1A). Exposure to LPS reduced the quartz-induced LDH production, such that an increase in LDH was only detectable in response to the $50 \mu \mathrm{g} / \mathrm{mL}$ dose $(p<0.001)$, and the LDH production at this dose was significantly lower than that of the cells exposed to the same dose of quartz without LPS $(p<0.001)$ (Figure 1A). Exposure to haematite had no effect on LDH levels ( $p>0.05$ for all doses) (Figure 1B). In the haematite trials, LPS caused a small but statistically significant decrease in LDH production $(p=0.02)$ (Figure 1B). In contrast, when cells were exposed to LPS in combination with haematite there was a small increase in LDH production at the $25 \mu \mathrm{g} / \mathrm{mL}$ dose $(p=0.04)$ that did not increase further with exposure to $50 \mu \mathrm{g} / \mathrm{mL}(p=0.74)$ (Figure 1B). Exposure to magnetite also increased LDH production at the $50 \mu \mathrm{g} / \mathrm{mL}$ dose $(p<0.001)$ (Figure 1C). Exposure to LPS changed the LDH-magnetite dose response relationship such that the increase in $\mathrm{LDH}$ production was detectable at $25 \mu \mathrm{g} / \mathrm{mL}(p=0.04)$ but did not reach the same level at $50 \mu \mathrm{g} / \mathrm{mL}$ as that seen in cells exposed to magnetite without LPS $(p<0.001)$ (Figure 1C).

\subsubsection{Interleukin-1 $\beta$}

Quartz induced a dose-dependent increase in interleukin-1 $\beta$ (IL-1 $\beta$ ) levels at $50 \mu \mathrm{g} / \mathrm{mL}$ $(p=0.03)$ (Figure 1D). LPS significantly augmented this response $(p<0.001$ for all doses) (Figure 1D). In contrast, haematite exposure did not alter IL-1 $\beta$ levels $(p>0.05$ for all doses) (Figure 1E). However, LPS resulted in significant increases in IL-1 $\beta$ expression at all concentrations $(p<0.003)$ (Figure 1E). This response was augmented by exposure to haematite with the highest IL-1 $\beta$ observed at $50 \mu \mathrm{g} / \mathrm{mL}(p<0.001)$ (Figure 1E). Similarly, magnetite alone had no effect on IL-1 $\beta$ production ( $p>0.05$ for all doses) (Figure 1F) but did enhance LPS-induced production of IL-1 $\beta$ with the highest expression observed at $50 \mu \mathrm{g} / \mathrm{mL}(p<0.001)$ (Figure 1F). 
A
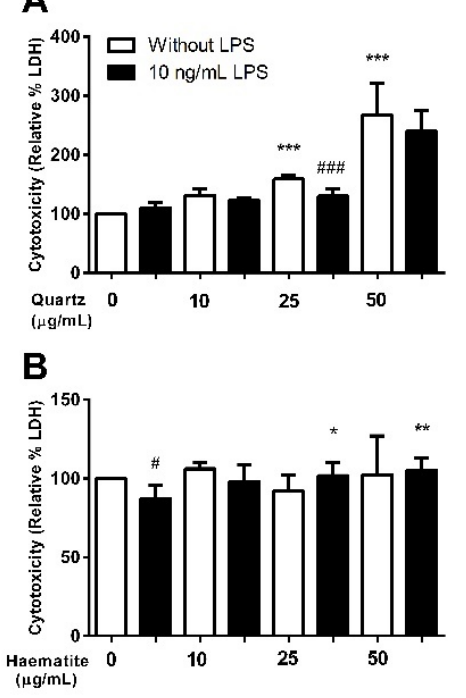

C

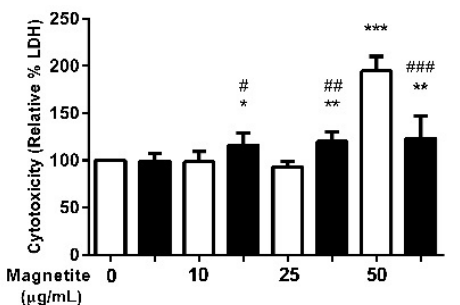

D

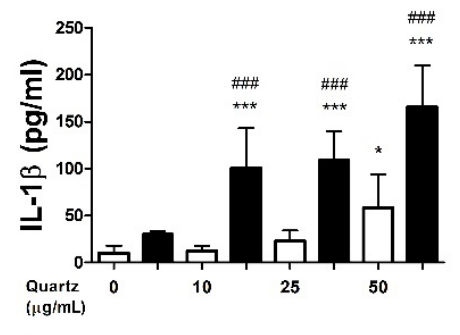

E

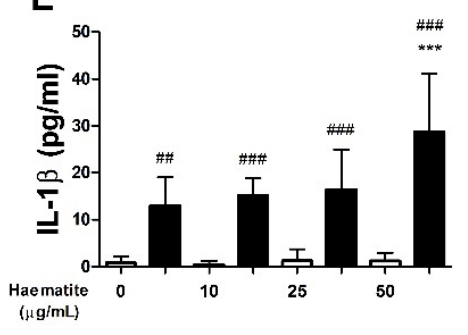

$\mathbf{F}$

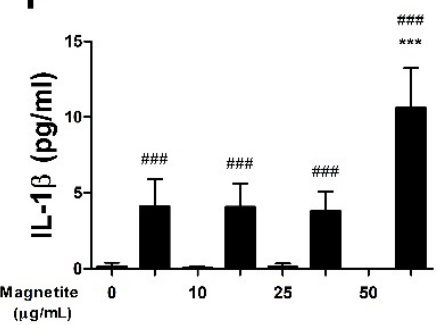

Figure 1. Lactate dehydrogenase (LDH; A-C) and IL-1 $\beta$ (D-F) levels in the supernatant of THP-1derived macrophages exposed to quartz $(\mathbf{A}, \mathbf{D})$, haematite $(\mathbf{B}, \mathbf{E})$ or magnetite $(\mathbf{C}, \mathbf{F})$ for $24 \mathrm{~h}$, with (black bars) or without (white bars) $4 \mathrm{~h}$ of prior lipopolysaccharide (LPS) exposure. LDH data are represented as a relative percentage increase in optical density value compared to the control $(100 \%)$. Data are presented as mean (SD) from 6 independent experiments. ${ }^{*}, * *$ and ${ }^{* * *}$ indicate $p<0.05$, $p<0.01$ and $p<0.001$ respectively versus control. \#, \#\# and \#\#\# indicate $p<0.05, p<0.01$ and $p<0.001$ respectively for LPS vs no LPS at the given dose.

\subsubsection{Interleukin-6}

Neither quartz (Figure 2A), haematite (Figure 2B) nor magnetite (Figure 2C) exposure caused any significant change in interleukin-6 (IL-6) production $(p>0.05$ for all doses) (Figure 2). LPS significantly increased IL-6 production ( $p<0.001$ for all doses) (Figure 2 ). Exposure to $50 \mu \mathrm{g} / \mathrm{mL}$ of quartz or haematite significantly enhanced the LPS-induced IL-6 production (quartz, $p=0.006$; haematite, $p<0.001$ ) (Figure 2A,B). In contrast, magnetite did not enhance the IL-6 response induced by LPS (Figure 2C).

\subsubsection{Interleukin-8}

Quartz induced an increase in interleukin-8 (IL-8) production (Figure 2D) which was detectable at $10 \mu \mathrm{g} / \mathrm{mL}(p=0.004)$ and did not increase further at higher particle doses $(p>0.05)$ (Figure 2D). LPS caused a profound effect on IL-8 production $(p<0.001$ for all doses) that was further enhanced by exposure to $10 \mu \mathrm{g} / \mathrm{mL}$ of quartz $(p=0.004)$ but did not increase further with higher doses of particles $(p>0.75)$ (Figure 2D). Haematite induced a dose-dependent increase in IL-8 which was detectable at $25 \mu \mathrm{g} / \mathrm{mL}(p=0.002)$ with no further increase at $50 \mu \mathrm{g} / \mathrm{mL}(p=0.56$ ) (Figure 2E). Exposure to haematite particles enhanced LPS-induced IL-8 production resulting in a similar dose-dependent response to that observed without LPS (Figure 2E). The same pattern was observed in response to magnetite, although the increase in IL- 8 with $(p=0.002)$ and without $(p=0.002)$ LPS was only observed at the $50 \mu \mathrm{g} / \mathrm{mL}$ particle dose (Figure $2 \mathrm{~F}$ ). 

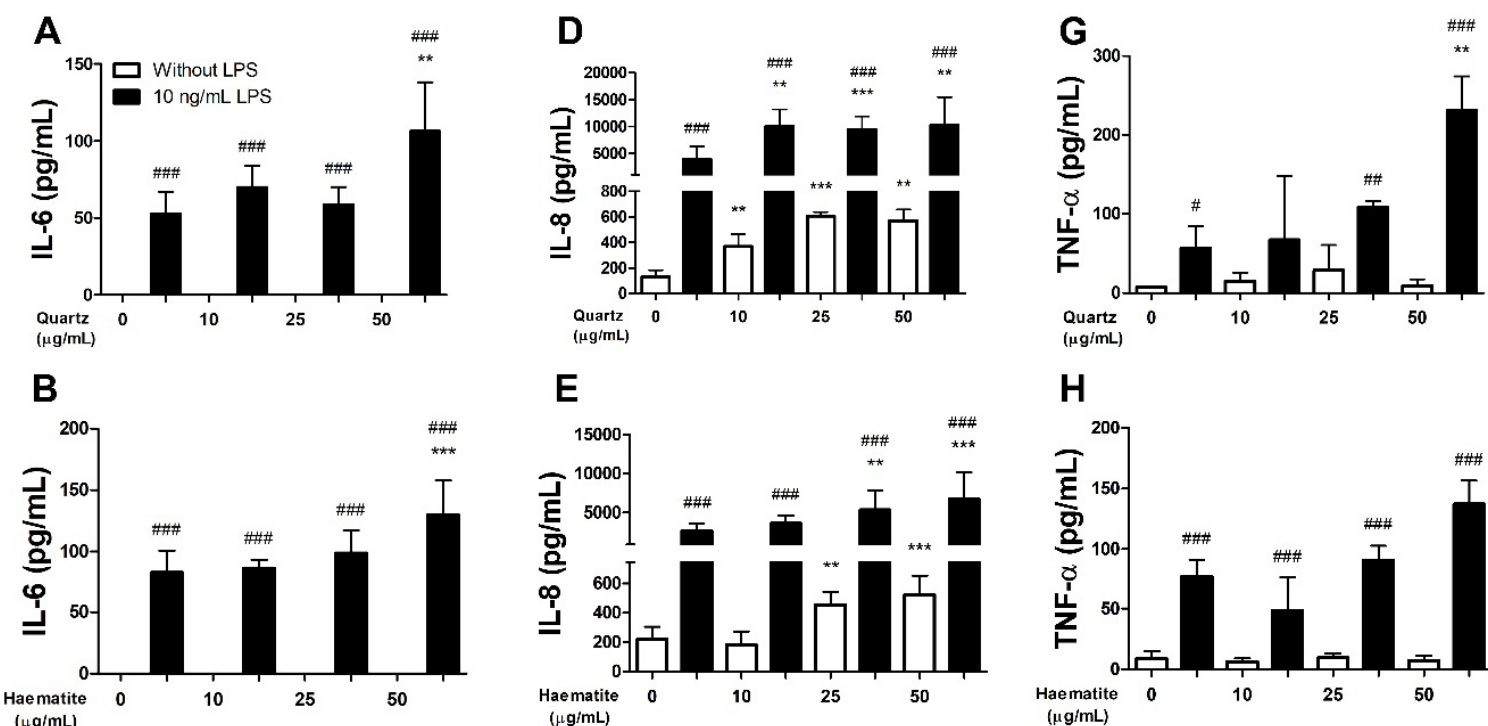

\section{E}

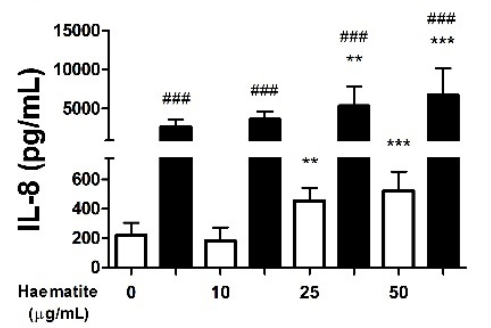

H
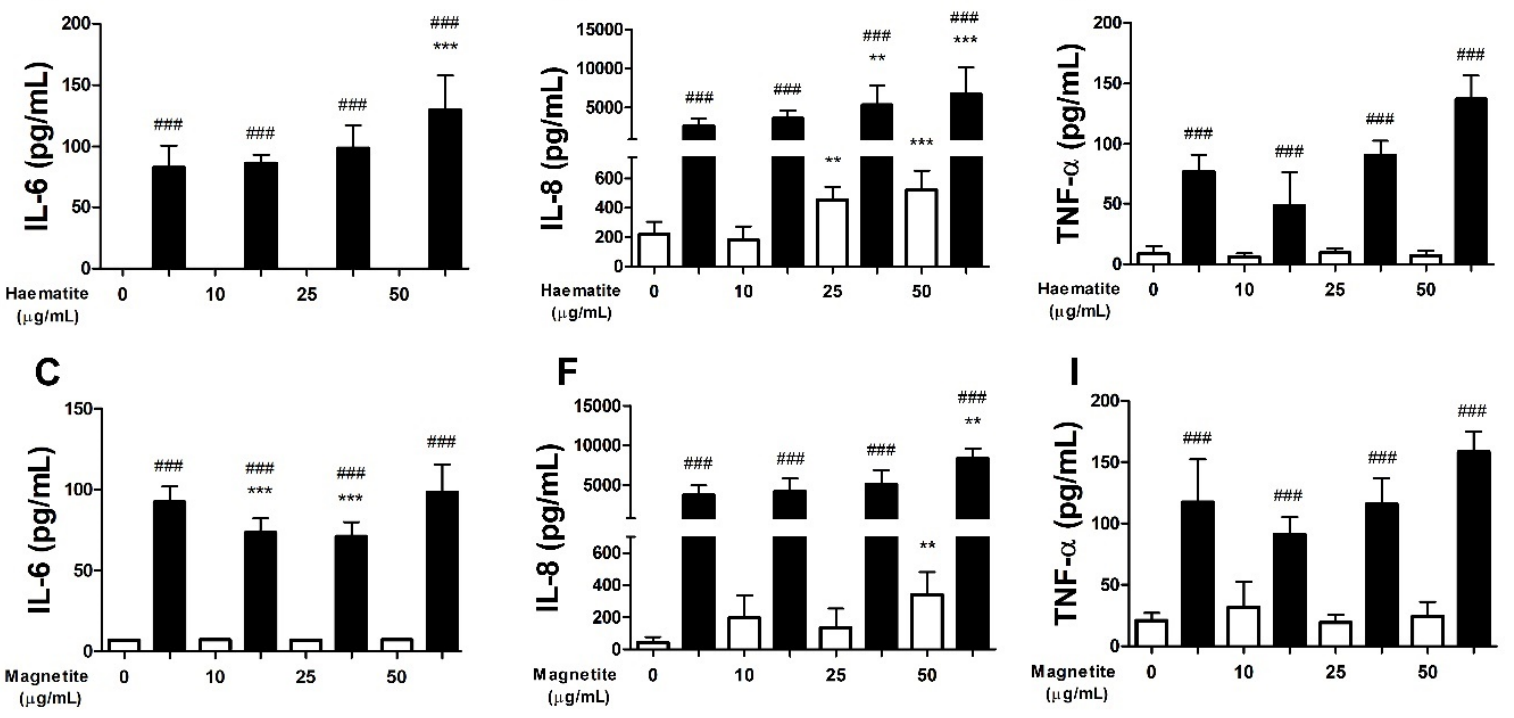

Figure 2. IL-1 $\beta$ (A-C), IL-8 (D-F) and TNF- $\alpha$ (G-I) levels in the supernatant of THP-1-derived macrophages exposed to quartz $(\mathbf{A}, \mathbf{D}, \mathbf{G})$, haematite $(\mathbf{B}, \mathbf{E}, \mathbf{H})$ or magnetite $(\mathbf{C}, \mathbf{F}, \mathbf{I})$ for $24 \mathrm{~h}$, with (black bars) or without (white bars) $4 \mathrm{~h}$ of prior lipopolysaccharide (LPS) exposure. Data are presented as mean (SD) from 6 independent experiments. ${ }^{* *}$ and ${ }^{* * *}$ indicate $p<0.01$ and $p<0.001$ respectively versus control. \#, \#\# and \#\#\# indicate $p<0.05, p<0.01$ and $p<0.001$ respectively for LPS vs no LPS at the given dose.

\subsubsection{Tumour Necrosis Factor- $\alpha$}

Tumour necrosis factor- $\alpha$ (TNF- $\alpha$ ) expression was not altered in response to quartz (Figure 2G), haematite (Figure 2H) or magnetite (Figure 2I) ( $p>0.05$ for all doses). LPS exposure increased the production of TNF- $\alpha$ which was enhanced further by exposure to $25(p=0.010)$ and $50 \mu \mathrm{g} / \mathrm{mL}(p<0.001)$ of quartz particles (Figure $2 \mathrm{G})$. In contrast, haematite $(p>0.09)$ and magnetite $(p=0.146)$ did not modify the LPS-induced increase in TNF- $\alpha$ production (Figure $2 \mathrm{H}, \mathrm{I}$ ).

\subsection{The Effect of Particles on NTHi Phagocytosis}

The effect of particle exposure on NTHi phagocytosis was assessed in six clinical isolates (Ci8, Ci34, Ci37, L267, L341 and NF3) [21]. There were variations in baseline levels of phagocytosis of the different isolates with higher phagocytosis of the Ci34 strain $(p<0.001)$ and lower levels of phagocytosis of the Ci37, Ci8 $(p<0.001)$ and L267 $(p=0.003)$ strains compared to the reference strain (NF3) (Figure 3). Compared to baseline levels of phagocytosis, haematite $(p=0.013)$ and magnetite $(p<0.001)$ decreased the internalisation of all strains of bacteria while quartz had no effect $(p=0.989)$. The effect of magnetite was greater than the effect of haematite $(p=0.010)$ (Figure 3). 


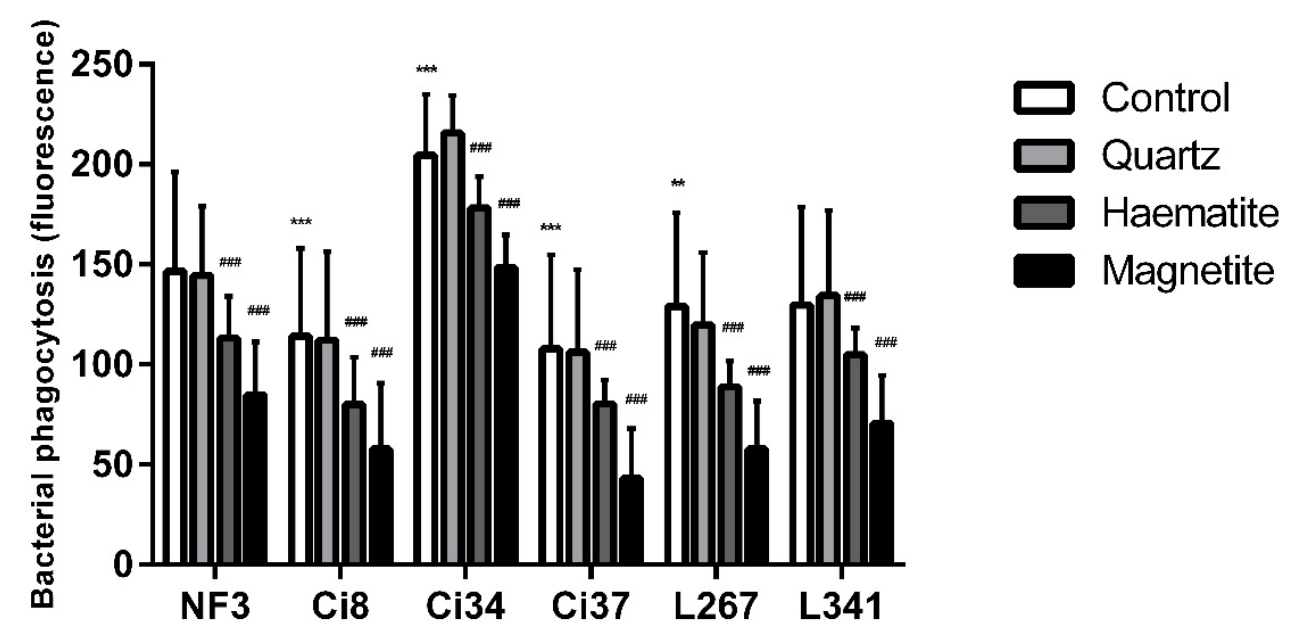

Figure 3. Relative phagocytosis of six NTHi isolates in THP-1-derived macrophage exposed to 0 or $50 \mu \mathrm{g} / \mathrm{mL}$ of quartz, haematite or magnetite or $24 \mathrm{~h}$. Data are presented as mean (SD) from 6 independent experiments. ${ }^{* *}$ and ${ }^{* * *}$ indicate $p<0.01$ and $p<0.001$ respectively versus NF3 control. \#\#\# indicates $p<0.001$ versus particle control within each isolate.

\subsection{Combined Effect of Quartz and Iron Oxide}

Having established the effect of iron oxide, and silica, particles alone on the response, we also assessed whether the combination of iron oxide and silica modified the response. We found that the combination exposure did not modify the individual responses we observed in terms of cytotoxicity, cytokine production or NTHi phagocytosis (data not shown).

\subsection{Responses in PBMCs}

\subsubsection{Cytotoxicity}

Quartz induced significant cytotoxicity when compared to control $(p=0.001)$, whereas haematite and magnetite $(p>0.47)$ had no cytotoxic effects in PBMCs (see Supplementary Materials Figure S2).

\subsubsection{Cytokine Production}

Similar to the response observed in THP-1 macrophages, only quartz induced IL$1 \beta$ production compared to control (Figure $4 \mathrm{~A}, p=0.017$ ) in PBMCs. Haematite and magnetite $(p>0.18)$ had no effect on IL-1 $\beta$ compared to control $(p>0.185)$. Only quartz increased IL-6 expression compared to control (Figure 4B, $p=0.047$ ). Conversely, both quartz (Figure $4 \mathrm{C}, p=0.001)$ and haematite $(p=0.003)$, but not magnetite $(p=0.125)$, increased IL-8 production when compared to control. However, the effect of quartz was higher than haematite $(p=0.012)$. There was no effect of any exposure on TNF- $\alpha$ production (Figure $4 \mathrm{D}, p>0.281$ ).

\subsubsection{NTHi Phagocytosis}

Like the THP-1 response, there were differences between NTHi strains (Figure 5; $p<0.05)$; however, the effect of particles on the response on PBMCs was different to that observed in THP-1 cells. In PBMCs, isolates L267 and L341 were phagocytosed less after exposure to haematite $(p<0.001$ and $p=0.028$ respectively), similar to observations of THP-1-derived macrophages. In contrast to the THP-1 data, there were no effects of particle exposure on the phagocytosis of the other isolates (Figure 5). 

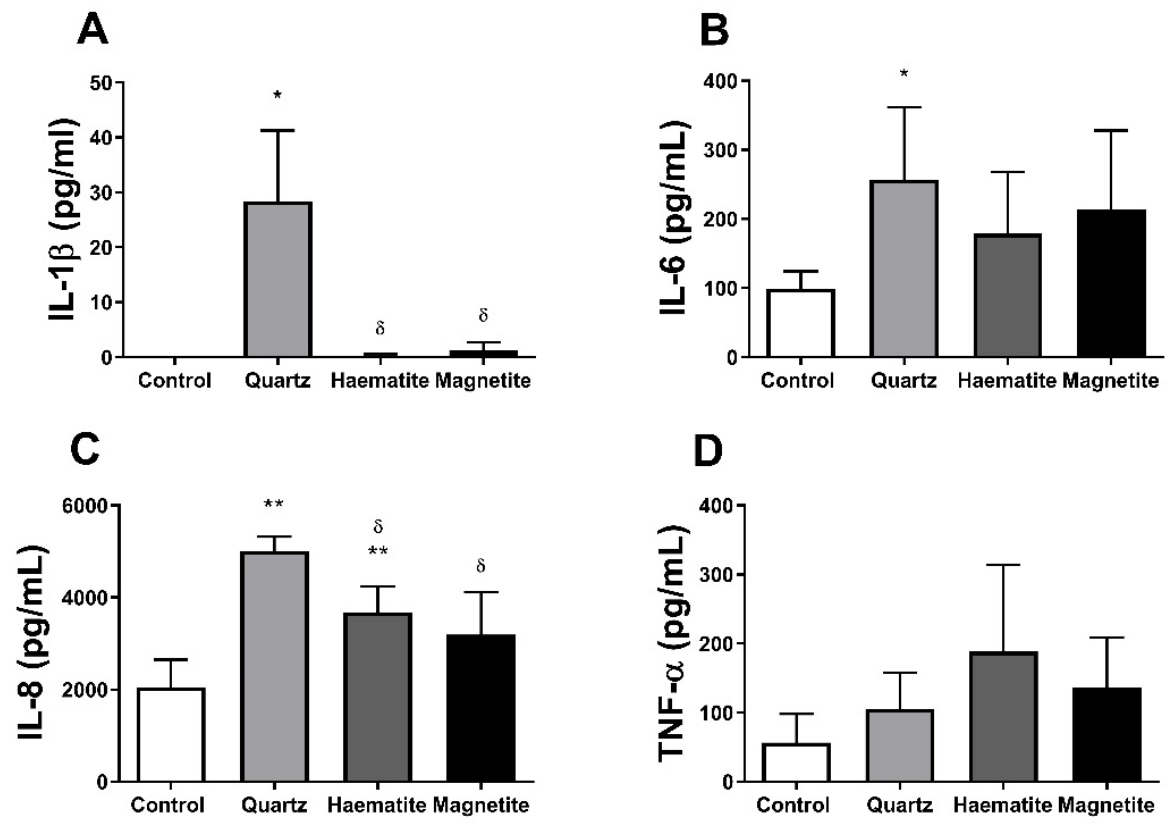

Figure 4. Interleukin (IL)-1 $\beta$ (A), IL-6 (B), IL-8 (C) and tumour necrosis factor (TNF)- $\alpha$ (D) levels in the supernatant of peripheral blood mononuclear cell (PBMC)-derived macrophages exposed to 0 or $50 \mu \mathrm{g} / \mathrm{mL}$ of quartz, haematite or magnetite for $24 \mathrm{~h}$. Data are presented as mean (SD) from 6 independent experiments. ${ }^{*}$ and ${ }^{* *}$ indicate $p<0.05$ and $p<0.01$ respectively versus control and $\delta$ indicates $p<0.05$ versus quartz.

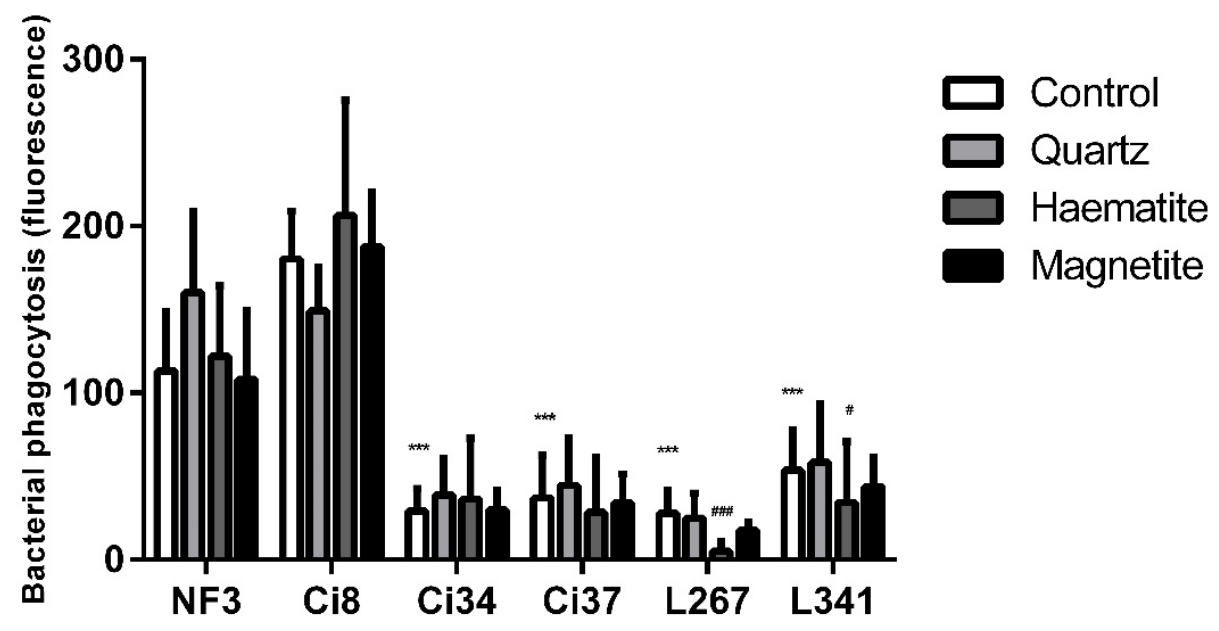

Figure 5. Relative phagocytosis of six NTHi isolates in PBMC-derived macrophage exposed to 0 or $50 \mu \mathrm{g} / \mathrm{mL}$ of quartz, haematite or magnetite or $24 \mathrm{~h}$. Data are presented as mean (SD) from 6 independent experiments. ${ }^{* * *}$ indicate $p<0.001$ versus NF3 control. \# and \#\#\# indicate $p<0.05$ and $p<0.001$ respectively versus particle control within each isolate.

\section{Discussion}

Regional Australian Aboriginal communities are exposed to high levels of geogenic particulate matter (Shepherd et al., 2019), dominated by silica and iron oxides (Zosky et al., 2014). These communities also have a disproportionate burden of chronic respiratory infections resulting in bronchiectasis (Blackall et al., 2018). The present study aimed to investigate the effect of iron oxide, with or without prior LPS exposure, on inflammation in macrophages and on bacterial phagocytosis as potential contributors to the detrimental 
health outcomes observed in individuals exposed to iron-laden geogenic PM [9]. Iron oxide particles clearly modified the effect of LPS on the macrophages, which varied between particle types and across cytokines. While haematite and magnetite had no effect on IL-1 $\beta$ production, they both enhanced LPS-induced IL-1 $\beta$ production in THP-1 cells. Similarly, quartz and haematite, but not magnetite, enhanced LPS-induced IL-6 production while all three particle types enhanced LPS-induced IL-8 in these cells. Similar responses to these particles were observed in PBMCs. Both haematite and magnetite, but not quartz, significantly decreased NTHi internalisation in THP-1 cells. However, only the effects of haematite were confirmed in PBMCs. Based on these observations, the previously observed link between exposure to iron-laden geogenic particles and poor respiratory health may be explained by the inflammatory effect on macrophages and the impairment of NTHi internalisation by these cells. The magnitude of these effects is likely to vary depending on the chemical composition of the inhaled particles (e.g., quartz vs haematite vs magnetite), whether there is a prior inflammatory stimulus present (e.g., infection) and the strain of NTHi present.

LPS is a component of the outer membrane of Gram-negative bacteria and is central to mediating the inflammatory response via binding to specific host receptors [22]. LPS binds to toll-like receptor (TLR)-4 [23], leading to the upregulation of NF- $\mathrm{KB}$, and enhanced transcription of a range of pro-inflammatory genes including IL- $1 \beta$, IL-6, IL-8 and TNF- $\alpha$ [24-26]. Accordingly, we found that LPS upregulated the expression of all the inflammatory cytokines we measured. The most overt difference between the effect of silica and iron oxide exposures was the release of IL- $1 \beta$ by quartz in absence of LPS. This effect of silica is consistent with results of previous studies and is likely to be driven by NF$\mathrm{KB}$-independent NOD-like receptor pyrin domain-containing 3 (NLRP-3) inflammasome activation [27-30]. It is worth noting the observed effect of quartz on cell cytotoxicity at the highest dose. This will have impacted on the capacity of the cells to produce cytokines, meaning that the relative increase in IL- 8 and IL-1 $\beta$ production in response to quartz is likely to be underestimated. The absence of an effect of iron oxide on the IL- $1 \beta$ production suggests that iron oxide is unable to activate this same pathway. While iron oxide nanoparticles can induce some level of IL- $1 \beta$, due to partial NLRP-3 activation, this is highly dependent on the shape of the particles [31], whereby spherical iron oxide particles, which have a similar morphology to the particles used in the present study [32], caused a minimal response in this pathway. The particles used in the present study were all in the $<5 \mu \mathrm{m}$ size range [32], which is consistent with the particle size observed in community sampled geogenic PM [33].

IL-8 is a neutrophil chemoattractant protein which can also be upregulated via NF- $\mathrm{KB}$ in response to LPS [34]. Our data showed that, in the absence of LPS, IL-8 was produced in response to all particle types. In epithelial cells, silica induces IL-8 through endocytosisindependent p38/AP-1 and ERK1/2/CEBP upregulation [23,35-37]. While the mechanism is unclear from our experiments, given the similarities between the IL-8 responses, it is possible that iron oxide particles may also activate the AP-1/CEBP pathway. This warrants further investigation.

IL-6 differs from the other cytokines discussed as it acts as both an anti-inflammatory mediator and macrophage activator [24]. IL-6 synthesis is initiated via multiple pathways including upregulation of NF- $\mathrm{KB}, \mathrm{CEBP}$ and IL-1 $\beta$ [38-45]. As expected, we observe a strong LPS-induced response. We also observed a modifying effect of the particles on this response. Interestingly, unlike both quartz and haematite, magnetite had a moderate suppressive effect on LPS-induced IL-6 at lower doses. As previously mentioned, IL-6 plays an anti-inflammatory role in the lung, supressing overexpression of TLRs, including TLR-4 [46]; magnetite may have the capacity to prevent this response. We saw no effect of any particle on IL-6 production in the absence of LPS, which is surprising given the increase in IL- $1 \beta$ production. Taken together, these observations suggest the regulation of IL-6 production in response to particles, and the modifying effect of these particles on the LPS response, is complex [47]. 
In contrast to quartz, both magnetite and haematite reduced the phagocytosis of NTHi by THP-1 macrophages. Given that quartz typically induced higher levels of inflammation in these cells than the iron oxides, the impairment in NTHi phagocytosis seems to be uncoupled from the inflammatory response. While the mechanism is unclear from our study, macrophage dysfunction has a profound impact on airway health. For example, mice with depleted macrophages are more susceptible to experimental pneumonia due to a lack of bacterial clearance [48,49]. Accordingly, a reduction in macrophage phagocytotic capacity in commonly found in bronchiectasis and is hypothesised to pre-empt, and probably contribute to the development of, the disease [50]. This highlights the importance of macrophage function and points to a possible mechanism linking exposure to geogenic particles and an increased risk of severe bacterial infection.

It is worth noting that some of the responses we observed in THP-1 cells were not replicated in the PBMC-derived macrophages. It is possible that this is due to the method of cell transformation. THP-1 were transformed using PMA, a commonly use protocol that yields an "M0" macrophage, whereas the GM-CSF used to transform the PBMC macrophages results in an "M1" phenotype. These phenotypic differences may impact on the phagocytic potential of the cells. Nonetheless, haematite still impacted NTHi phagocytosis in some strains in the PBMCs, suggesting that the impact of iron oxide is preserved across macrophage sub-types.

Limitations of the present study must be acknowledged. While we have investigated the effects and interactions of the two major components of geogenic PM on the cell response, silica and iron oxide do not fully represent geogenic PM in its entirety, nor do they fully represent the vast heterogeneity of naturally occurring geogenic PM. We chose to focus on silica and iron oxide as these are the two constituents that have shown the most robust correlation with negative health outcomes in previous studies [33,51]. Lastly, we utilised a commonly found cell line and transformed primary macrophages from the circulation, neither of which display the same phenotype as primary alveolar macrophages. However, the consistency of the inflammatory responses, and some of the phagocytosis response, in the different macrophage types we used suggests that it is likely that the effect of iron oxide particles we have shown is conserved across macrophages with different phenotypes.

\section{Conclusions}

The present study has confirmed the pro-inflammatory potential of inhalable quartz in macrophages, but importantly has also shown that haematite, the most common iron oxide found in the dusts affecting regional Australian Aboriginal communities, modifies the inflammation induced by a bacterial stimulus and the ability of macrophages to phagocytose NTHi. Haematite has long been viewed as a biologically inert particle due to its mild inflammatory profile. However, our results provide novel evidence that iron oxide suppresses NTHi phagocytosis which may contribute to the high burden of pathogenic respiratory NTHi infection in at-risk communities. This has important implications for all individuals exposed to iron-laden particulates.

Supplementary Materials: The following are available online at https:/ / www.mdpi.com/1660-460 1/18/1/146/s1, Figure S1: Example flow cytometry analysis of peripheral blood mononuclear cell (PBMC)-derived macrophages phagocytosing NTHi, Figure S2: Lactate dehydrogenase (LDH) in the supernatant of PBMC-derived macrophages exposed to quartz, haematite or magnetite for $24 \mathrm{~h}$.

Author Contributions: Conceptualisation, L.J.W., S.G.T. and G.R.Z.; methodology, L.J.W., S.G.T. and G.R.Z.; formal analysis, L.J.W. and G.R.Z.; investigation, L.J.W. and S.G.T.; resources, S.G.T. and G.R.Z.; data curation, L.J.W. and G.R.Z.; writing—original draft preparation, L.J.W.; writing-review and editing, S.G.T. and G.R.Z.; visualisation, L.J.W. and G.R.Z.; supervision, S.G.T. and G.R.Z.; funding acquisition, L.J.W. and G.R.Z. All authors have read and agreed to the published version of the manuscript. 
Funding: This research was funded by Australian Respiratory Council (Harry Windsor Grant) and Centre for Air Pollution, Energy and Health Research (PhD project grant).

Institutional Review Board Statement: The study was approved by the University of Tasmania Human Research Ethics Committee (H0016505; approved on 23/08/2017).

Informed Consent Statement: Informed consent was obtained from all subjects involved in the study.

Data Availability Statement: The data presented in this study are available on request from the corresponding author.

Conflicts of Interest: The funders had no role in the design of the study; in the collection, analyses, or interpretation of data; in the writing of the manuscript, or in the decision to publish the results. The authors declare no conflict of interest.

\section{References}

1. $\quad$ Loebinger, M.R.; Wells, A.U.; Hansell, D.M.; Chinyanganya, N.; Devaraj, A.; Meister, M.; Wilson, R. Mortality in bronchiectasis: A long-term study assessing the factors influencing survival. Eur. Respir. J. 2009, 34, 843. [CrossRef] [PubMed]

2. Blackall, S.R.; Hong, J.B.; King, P.; Wong, C.; Einsiedel, L.; Remond, M.G.W.; Woods, C.; Maguire, G.P. Bronchiectasis in indigenous and non-indigenous residents of Australia and New Zealand. Respirology 2018, 23, 743-749. [CrossRef] [PubMed]

3. Chang, A.B.; Grimwood, K.; Mulholland, E.K.; Torzillo, P.J. Bronchiectasis in indigenous children in remote Australian communities. Med. J. Aust. 2002, 177, 200-204. [CrossRef] [PubMed]

4. Australian Bureau of Statistics. Aboriginal and Torres Strait Islander Peoples: Smoking trends, Australia, 1994 to 2014-15; Australian Bureau of Statistics: Canberra, Australia, 2017.

5. Melody, S.M.; Bennett, E.; Clifford, H.D.; Johnston, F.H.; Shepherd, C.C.J.; Alach, Z.; Lester, M.; Wood, L.J.; Franklin, P.; Zosky, G.R. A cross-sectional survey of environmental health in remote Aboriginal communities in Western Australia. Int. J. Environ. Health Res. 2016, 26, 525-535. [CrossRef] [PubMed]

6. O'Grady, K.A.; Torzillo, P.J.; Chang, A.B. Hospitalisation of Indigenous children in the Northern Territory for lower respiratory illness in the first year of life. Med. J. Aust. 2010, 192, 586-590. [CrossRef] [PubMed]

7. Clifford, H.; Pearson, G.; Franklin, P.; Walker, R.; Zosky, G. Environmental health challenges in remote Aboriginal Australian communities: Clean air, clean water and safe housing. Aust. Indig. Health Bull. 2015, 15, 1-13.

8. Clifford, H.; Teo, T.; Kirkham, L.A.; Thornton, R.; Zosky, G.; Pickering, J. Dust exposure impacts haemophilus influenzae attachment and invasion of human airway epithelial cells. Eur. Respir. J. 2016, 48, PA4266.

9. Shepherd, C.C.J.; Clifford, H.D.; Mitrou, F.; Melody, S.M.; Bennett, E.J.; Johnston, F.H.; Knibbs, L.D.; Pereira, G.; Pickering, J.L.; Teo, T.H.; et al. The contribution of geogenic particulate matter to lung disease in indigenous children. Int. J. Environ. Res. Public Health 2019, 16, 2636. [CrossRef]

10. Goeminne, P.C.; Cox, B.; Finch, S.; Loebinger, M.R.; Bedi, P.; Hill, A.T.; Fardon, T.C.; de Hoogh, K.; Nawrot, T.S.; Chalmers, J.D. The impact of acute air pollution fluctuations on bronchiectasis pulmonary exacerbation: A case-crossover analysis. Eur. Respir. J. 2018, 52, 1702557. [CrossRef]

11. Goeminne, P.C.; Bijnens, E.; Nemery, B.; Nawrot, T.S.; Dupont, L.J. Impact of traffic related air pollution indicators on non-cystic fibrosis bronchiectasis mortality: A cohort analysis. Respir. Res. 2014, 15, 108. [CrossRef]

12. Pinto, E.H.; Longo, P.L.; Camargo, C.C.B.D.; Dal Corso, S.; Lanza, F.D.C.; Stelmach, R.; Athanazio, R.; Fernandes, K.P.S.; Mayer, M.P.A.; Bussadori, S.K.; et al. Assessment of the quantity of microorganisms associated with bronchiectasis in saliva, sputum and nasal lavage after periodontal treatment: A study protocol of a randomised controlled trial. Bmj Open 2016, 6, e010564. [CrossRef] [PubMed]

13. Pizzutto, S.J.; Hare, K.M.; Upham, J.W. Bronchiectasis in children: Current concepts in immunology and microbiology. Front. Pediatrics 2017, 5, 123. [CrossRef] [PubMed]

14. Watson, K.; Carville, K.; Bowman, J.; Jacoby, P.; Riley, T.V.; Leach, A.J.; Lehmann, D. Upper respiratory tract bacterial carriage in Aboriginal and non-Aboriginal children in a semi-arid area of Western Australia. Pediatric Infect. Dis. J. 2006, 25, 782-790. [CrossRef] [PubMed]

15. Angrill, J.; Agustí, C.; de Celis, R.; Rañó, A.; Gonzalez, J.; Solé, T.; Xaubet, A.; Rodriguez-Roisin, R.; Torres, A. Bacterial colonisation in patients with bronchiectasis: Microbiological pattern and risk factors. Thorax 2002, 57, 15. [CrossRef] [PubMed]

16. Clifford, H.D.; Perks, K.L.; Zosky, G.R. Geogenic PM 10 exposure exacerbates responses to influenza infection. Sci. Total Environ. 2015, 533, 275-282. [CrossRef]

17. Williams, L.J.; Tristram, S.G.; Zosky, G.R. Inorganic particulate matter modulates non-typeable Haemophilus influenzae growth: A link between chronic bacterial infection and geogenic particles. Environ. Geochem. Health 2019, 42, 2137-2145. [CrossRef]

18. Geiser, M.; Casaulta, M.; Kupferschmid, B.; Schulz, H.; Semmler-Behnke, M.; Kreyling, W. The role of macrophages in the clearance of inhaled ultrafine titanium dioxide particles. Am. J. Respir. Cell Mol. Biol. 2008, 38, 371-376. [CrossRef]

19. Lehnert, B.E. Pulmonary and thoracic macrophage subpopulations and clearance of particles from the lung. Environ. Health Perspect. 1992, 97, 17-46. [CrossRef] 
20. Marti-Lliteras, P.; Regueiro, V.; Morey, P.; Hood, D.W.; Saus, C.; Sauleda, J.; Agusti, A.G.; Bengoechea, J.A.; Garmendia, J. Nontypeable Haemophilus influenzae clearance by alveolar macrophages is impaired by exposure to cigarette smoke. Infect. Immun. 2009, 77, 4232-4242. [CrossRef]

21. Singh, N.K.; Kunde, D.A.; Tristram, S.G. Effect of epithelial cell type on in vitro invasion of non-typeable Haemophilus influenzae. J. Microbiol. Methods 2016, 129, 66-69. [CrossRef]

22. Munford, R.S. Sensing gram-negative bacterial lipopolysaccharides: A human disease determinant? Infect. Immun. 2008, 76, 454-465. [CrossRef] [PubMed]

23. Ovrevik, J.; Lag, M.; Schwarze, P.; Refsnes, M. p38 and Src-ERK1/2 pathways regulate crystalline silica-induced chemokine release in pulmonary epithelial cells. Toxicol. Sci. 2004, 81, 480-490. [CrossRef] [PubMed]

24. Tanaka, T.; Narazaki, M.; Kishimoto, T. IL-6 in inflammation, immunity, and disease. Cold Spring Harb. Perspect. Biol. 2014, 6, a016295. [CrossRef] [PubMed]

25. Jundi, K.; Greene, C.M. Transcription of interleukin-8: How altered regulation can affect cystic fibrosis lung disease. Biomolecules 2015, 5, 1386-1398. [CrossRef]

26. Lopez-Castejon, G.; Brough, D. Understanding the mechanism of IL-1beta secretion. Cytokine Growth Factor Rev. 2011, 22, 189-195. [CrossRef]

27. Shao, B.-Z.; Xu, Z.-Q.; Han, B.-Z.; Su, D.-F.; Liu, C. NLRP3 inflammasome and its inhibitors: A review. Front. Pharmacol. 2015, 6, 262. [CrossRef]

28. Gómez, D.M.; Urcuqui-Inchima, S.; Hernandez, J.C. Silica nanoparticles induce NLRP3 inflammasome activation in human primary immune cells. Innate Immun. 2017, 23, 697-708. [CrossRef]

29. Peeters, P.M.; Eurlings, I.M.J.; Perkins, T.N.; Wouters, E.F.; Schins, R.P.F.; Borm, P.J.A.; Drommer, W.; Reynaert, N.L.; Albrecht, C. Silica-induced NLRP3 inflammasome activation in vitro and in rat lungs. Part. Fibre Toxicol. 2014, 11, 58. [CrossRef]

30. He, Y.; Hara, H.; Núñez, G. Mechanism and regulation of NLRP3 inflammasome activation. Trends Biochem. Sci. 2016, 41, 1012-1021. [CrossRef] [PubMed]

31. Liu, L.; Sha, R.; Yang, L.; Zhao, X.; Zhu, Y.; Gao, J.; Zhang, Y.; Wen, L.-P. Impact of morphology on iron oxide nanoparticles-induced inflammasome activation in macrophages. ACS Appl. Mater. Interfaces 2018, 10, 41197-41206. [CrossRef] [PubMed]

32. Williams, L.J.; Zosky, G.R. The inflammatory effect of iron oxide and silica particles on lung epithelial cells. Lung 2019, 197, 199-207. [CrossRef] [PubMed]

33. Zosky, G.R.; Iosifidis, T.; Perks, K.; Ditcham, W.G.F.; Devadason, S.G.; Siah, W.S.; Devine, B.; Maley, F.; Cook, A. The concentration of iron in real-world geogenic $\mathrm{PM}_{10}$ is associated with increased inflammation and deficits in lung function in mice. PLoS ONE 2014, 9, e90609. [CrossRef] [PubMed]

34. Andreakos, E.; Sacre, S.M.; Smith, C.; Lundberg, A.; Kiriakidis, S.; Stonehouse, T.; Monaco, C.; Feldmann, M.; Foxwell, B.M. Distinct pathways of LPS-induced NF-kB activation and cytokine production in human myeloid and nonmyeloid cells defined by selective utilization of MyD88 and Mal/TIRAP. Blood 2004, 103, 2229-2237. [CrossRef] [PubMed]

35. Stein, B.; Baldwin, A.S. Distinct mechanisms for regulation of the interleukin-8 gene involve synergism and cooperativity between C/EBP and NF-kappa B. Mol. Cell. Biol. 1993, 13, 7191-7198. [CrossRef] [PubMed]

36. Roebuck, K.A. Regulation of interleukin-8 gene expression. J. Interferon Cytokine Res. 1999, 19, 429-438. [CrossRef]

37. Hipp, M.S.; Urbich, C.; Mayer, P.; Wischhusen, J.; Weller, M.; Kracht, M.; Spyridopoulos, I. Proteasome inhibition leads to NF-kappaB-independent IL-8 transactivation in human endothelial cells through induction of AP-1. Eur. J. Immunol. 2002, 32, 2208-2217. [CrossRef]

38. Bannach, F.G.; Gutierrez-Fernandez, A.; Parmer, R.J.; Miles, L.A. Interleukin-6-induced plasminogen gene expression in murine hepatocytes is mediated by transcription factor CCAAT/enhancer binding protein beta (C/EBPbeta). J. Thromb. Haemost. 2004, 2, 2205-2212. [CrossRef]

39. Young, D.P.; Kushner, I.; Samols, D. Binding of C/EBPbeta to the C-reactive protein (CRP) promoter in Hep3B cells is associated with transcription of CRP mRNA. J. Immunol. 2008, 181, 2420-2427. [CrossRef]

40. Hershko, D.D.; Robb, B.W.; Luo, G.; Hasselgren, P.O. Multiple transcription factors regulating the IL-6 gene are activated by cAMP in cultured Caco-2 cells. Am. J. Physiol. Regul. Integr. Comp. Physiol. 2002, 283, R1140-R1148. [CrossRef]

41. Hattori, T.; Ohoka, N.; Hayashi, H.; Onozaki, K. C/EBP homologous protein (CHOP) up-regulates IL-6 transcription by trapping negative regulating NF-IL6 isoform. FEBS Lett. 2003, 541, 33-39. [CrossRef]

42. Hungness, E.S.; Luo, G.J.; Pritts, T.A.; Sun, X.; Robb, B.W.; Hershko, D.; Hasselgren, P.O. Transcription factors C/EBP-beta and -delta regulate IL-6 production in IL-1beta-stimulated human enterocytes. J. Cell. Physiol. 2002, 192, 64-70. [CrossRef] [PubMed]

43. Hungness, E.S.; Pritts, T.A.; Luo, G.J.; Sun, X.; Penner, C.G.; Hasselgren, P.O. The transcription factor activator protein-1 is activated and interleukin-6 production is increased in interleukin-1beta-stimulated human enterocytes. Shock 2000, 14, 386-391. [CrossRef] [PubMed]

44. Tuyt, L.M.; Dokter, W.H.; Birkenkamp, K.; Koopmans, S.B.; Lummen, C.; Kruijer, W.; Vellenga, E. Extracellular-regulated kinase $1 / 2$, Jun N-terminal kinase, and c-Jun are involved in NF-kappa B-dependent IL-6 expression in human monocytes. J. Immunol. 1999, 162, 4893-4902. [PubMed]

45. Miyazawa, K.; Mori, A.; Yamamoto, K.; Okudaira, H. Transcriptional roles of CCAAT/enhancer binding protein-beta, nuclear factor-kappaB, and C-promoter binding factor 1 in interleukin (IL)-1beta-induced IL-6 synthesis by human rheumatoid fibroblastlike synoviocytes. J. Biol. Chem. 1998, 273, 7620-7627. [CrossRef] 
46. Inoue, K.; Takano, H.; Yanagisawa, R.; Sakurai, M.; Shimada, A.; Morita, T.; Sato, M.; Yoshino, S.; Yoshikawa, T. Role of interleukin-6 in toll-like receptor 4 and 2 expressions induced by lipopolysaccharide in the lung. Immunopharmacol. Immunotoxicol. 2007, 29, 63-68. [CrossRef]

47. Kusaka, T.; Nakayama, M.; Nakamura, K.; Ishimiya, M.; Furusawa, E.; Ogasawara, K. Effect of silica particle size on macrophage inflammatory responses. PLoS ONE 2014, 9, e92634. [CrossRef]

48. Knapp, S.; Leemans, J.C.; Florquin, S.; Branger, J.; Maris, N.A.; Pater, J.; van Rooijen, N.; van der Poll, T. Alveolar macrophages have a protective antiinflammatory role during murine pneumococcal pneumonia. Am. J. Respir. Crit. Care Med. 2003, 167, 171-179. [CrossRef]

49. Kooguchi, K.; Hashimoto, S.; Kobayashi, A.; Kitamura, Y.; Kudoh, I.; Wiener-Kronish, J.; Sawa, T. Role of alveolar macrophages in initiation and regulation of inflammation in Pseudomonas aeruginosa pneumonia. Infect. Immun. 1998, 66, 3164-3169. [CrossRef]

50. Hodge, S.; Upham, J.W.; Pizzutto, S.; Petsky, H.L.; Yerkovich, S.; Baines, K.J.; Gibson, P.; Simpson, J.L.; Buntain, H.; Chen, A.C.H.; et al. Is alveolar macrophage phagocytic dysfunction in children with protracted bacterial bronchitis a forerunner to bronchiectasis? Chest 2016, 149, 508-515. [CrossRef]

51. Zosky, G.R.; Boylen, C.E.; Wong, R.S.; Smirk, M.N.; Gutierrez, L.; Woodward, R.C.; Siah, W.S.; Devine, B.; Maley, F.; Cook, A. Variability and consistency in lung inflammatory responses to particles with a geogenic origin. Respirology 2014, 19, 58-66. [CrossRef] 